\title{
Micro-Place Disorder, Subjective Powerlessness and Violent Youth Group Involvement: Testing an Integrative Control Theory
}

\author{
Lieven J.R. Pauwels ${ }^{1, *}$ and Robert Svensson ${ }^{2}$ \\ ${ }^{1}$ Department of Penal Law and Criminology, Ghent University, Ghent, Belgium \\ ${ }^{2}$ Malmö University, Malmö, Sweden
}

\begin{abstract}
In this study we test an integrative theory that seeks to explain why youth that live in disordered micro-places have an increase likelihood of becoming involved in a violent youth group. The emerging integrative theory is based on the principle of conceptual end-to-end integration and is the result of an attempt to integrate (1) a contemporary version of subjective powerlessness theory with (2) an integrative control framework of violent youth group involvement. We submit the thesis that the both aforementioned models are highly suitable for conceptual integration as micro-place disorder is a common antecedent. In addition, both models share an intervening mechanism in the observed micro-place disorder- violent youth group involvement relationship: the concept of normlessness. An integrative model allows for the study of multiple pathways through which micro-place disorder and subjective powerlessness affect the likelihood of becoming involved in a violent youth group. Using path analyses for continuous and dichotomous outcomes we test key propositions of our theoretical elaboration. Our research is based on a large sample of youths in early adolescence $(\mathrm{N}=2,486)$ in the urban context of Antwerp, the second largest city of Belgium. The results indicate that micro-place disorder increases decreases parental monitoring and increases feelings of subjective powerlessness. Normlessness and low self-control are important mediators in the "causal chain" between micro-place disorder, subjective powerlessness and violent youth group involvement. Low self-control and lifestyle risk further mediate the effects of subjective powerlessness, normlessness and micro-place disorder. The implications of these findings for future studies of violent youth group involvement are discussed.
\end{abstract}

Keywords: Subjective powerlessness, violent youth group involvement, integrative theory, micro-place disorder, low self-control, lifestyle risk.

\section{INTRODUCTION}

The goal of the present study is to examine the links between micro-place disorder, subjective powerlessness and violent youth group involvement (henceforth: VYG). The basic research question is how averse micro-place conditions may affect the likelihood of VYG? We submit that this may not only happen through the impact of adverse neighborhood conditions on social controls and conventional beliefs but also through the installation of subjective powerlessness, i.e. a mood of fatalism, which, according to David Matza (1964) neutralizes conventional bonds to society. The idea that adverse micro-place conditions foster crime and violent youth group involvement has a long and outstanding tradition in social disorganization theory and its contemporary counterparts, such as the systemic model of neighborhood organization (Bursick and Grasmick 1993; Sampson 2012). The role of subjective powerlessness is less clear in criminological theories. We argue that it is highly plausible to suspect a link between adverse micro-place conditions, subjective powerlessness and violent youth group involvement based on a number of observations.

There exists a longstanding tradition outside criminology that linked societal and neighborhood

*Address correspondence to this author at the Department of Penal Law and Criminology, Ghent University, B-9000 Gent, Belgium; Tel: +32 (0) 926468 37; Fax: +32 (0) 926469 88; E-mail: Lieven.Pauwels@Ugent.be conditions to subjective powerlessness (Ross and Mirowsky 1987; Seeman 1991). Probably the most known framework is Mirowsky and Ross' (2009) conditions-cognitions-emotion theory, which has its roots in alienation theory. This theoretical framework holds that neighborhood disorder fosters normlessness and subjective powerlessness. Conditions-cognitionsemotions theory holds that adverse conditions in neighborhoods foster subjective powerlessness and normlessness, which in turn may increase a number of negative outcomes such as distrust, illegal political protest, ... We apply that idea to the study of VYG. Actually, we develop the idea that the core theoretical propositions of conditions-cognitions-emotions theory can be conceptually integrated in contemporary neighborhood condition models that stress the role of controls and conventional beliefs, low self-control and unstructured routines as mediators of the relationship between neighborhood conditions and violent youth group involvement. Inspired by the analytical tradition in sociology we develop an integrated framework which allows for empirically testing our key research question. $^{1}$ We aim to provide a deep causal

${ }^{1}$ It has previously argued that the application of the basic mechanism-based philosophy of the analytical approach in sociology can be labeled with the term "analytical criminology" (Pauwels, Ponsaers and Svensson 2010). Also Wikström uses the term analytical criminology in a similar way (Wikström 2012).

〔C 2014 Lifescience Global 
explanation, i.e. a causal explanation that cites the mechanisms involved in the process (Hedström 2005; Elster 1989). Thus, a plausible and informative integrated model that builds on elements of the aforementioned theoretical traditions needs to be developed guided by the principles of conceptual endto-end integration (Messner, Krohn and Liska 1989). The result should be an informative theory that sequentially hooks together concepts from the aforementioned theories. The empirical test should allow us to either corroborate or falsify the premises derived from our integrated model.

The search for explanations of individual and ecological differences in youth gang involvement has played a prominent role in criminology for a long time. From a historical point of view, social disorganization theory has played a major role in the development of theories of gang membership (Thrasher 1927). Frederic Thrasher who conducted a study of 1,313 gangs in the city of Chicago during the early 1920s concluded that:

"...gangland represents a geographically and socially interstitial area in the city. Probably the most significant concept of the study is the term interstitial - that is, pertaining to spaces that intervene between one thing and another. In nature foreign matter tends to collect and cake in every crack, crevice, and cranny interstices. There are also fissures and breaks in the structure of social organization. The gang may be regarded as an interstitial region in the layout of the city. (1927/1966: 20)".

Thrasher continuous to inspire contemporary work on neighborhoods and gang violence (Braga, Papachristos and Hureau 2010; Papachristos 2006). After the temporary demise of Shaw and McKay's disorganization theory, the study of youth gangs reemerged in the 1950s in the heydays of Merton's anomietradition. The 1950s saw the rise of early subcultural theories (Cohen 1955; Miller 1959) and Cloward and Ohlins' (1960) differential opportunity theory which combined elements of Merton's strain perspective and Sutherlands' differential association tradition. A recurrent theme in these early subcultural and strain theories of gang membership was that gang members shared a strong belief in fate (fatalism) and destiny. Scholars such as Miller (1958) stressed that gang members lacked a personal belief in the ability to control their own future. Sociologists back then used the concept of subjective powerlessness to refer to this fatalism. In the Mertonian tradition, subjective powerlessness was placed in the lower strata as a consequence of goal blockage or the structural impediments that were placed on the living conditions of individuals in the lower strata. The concept of subjective powerlessness was paramount in alienation theory. ${ }^{2}$ Influential advocates of alienation theory were Leo Srole (1956) who focused on anomia or political powerlessness and Melvin Seeman (1959) who developed his theory of subjective alienation. Alienation theory was a popular theory that was used for the explanation of political violence amongst the lower strata in the turmoil of the 1960 and 1970s (Portes 1971; Opp 2009). In the 1960s the concept of subjective powerlessness reappears under the name of external locus of control under the influence of psychology (Rutter 1966).

While the early scholars of gang membership referred to subjective powerlessness as a characteristic of gang members, the empirical evidence of a relationship between subjective powerlessness and gang membership is lacking. This lack of empirical data is highly suggestive for a loss of interest among scholars in the concept of subjective alienation. Why? We submit five plausible reasons.

Firstly, gang theorists might have lost their interest in the concept of subjective powerlessness associologists struggled with the meaning and they key concepts of subjective powerlessness and alienation. Indeed, even die-hard alienation theorist such as Seeman $(1975 ; 1991)$ acknowledges the lack of consensus over the meaning of alienation and the struggle among alienation theorists. The same can be said of the concept of locus of control.

Secondly, the emergence of other theoretical frameworks re-addressed the attention of scholars to explore the applicability of these newer frameworks to the study of gang membership. Examples can be found in control theories (Short and Strodtbeck 1965; Kornhauser 1978), life style/routine activities theories

\footnotetext{
${ }^{2}$ From a historical point of view, alienation goes back to both the writings of Marx and Durkheim. Hayden and Smith (2008) have argued that criminologists have followed the Durkheimian tradition. In this paper we are interested in the focus of subjective powerlessness in the sense of external locus of control $/$ fatalism. A full description of the historical development of the concept of alienation (both Marxian and Durkheimian) goes beyond the scope of the present study. Scholars may consult the interesting paper by Hayden and Smith (2008) as a starting point for further reading.
} 
(Maxfield 1987; Riley 1987; Forde and Kennedy 1997) self-control theory (Hope and Damphousse 2002).

Thirdly, the increased interest in theoretical integration of traditional offending theories did not remain undetected by scholars of gang membership: an increased interest in theoretical integration after years of competitive theory testing gave rise to a number of studies that aimed at integrating the major classic perspectives in the etiology of offending and pushed scholars of gang membership to evaluate the possibility of applying the key perspectives in the etiology of offending to the study of gang membership. Indeed, previous studies have successfully demonstrated that integrative frameworks for the explanation of offending can be successfully applied to the explanation of VYG (Esbensen et al. 2010; Kissner and Pyrooz 2009).

Fourthly, In the 1990s developmental and life course theories hit criminology and stimulated scholars' interest to develop newer theories such as Thornberry's interactional theory (see Thornberry 1987; Thornberry, Hawkins and Krohn 1998) and Laub and Sampson's(2003) age-graded informal control theory and recently Wood and Alleyne's (2010) unified framework, a promising overarching framework for the study of causes and consequences of gang membership.

Fiftly, previous studies on the relation between delinquency and subjective powerlessness/ external locus of control have been inconsistent. Some studies have found delinquents to be more external in control (Duke and Fenhagen 1975; Ransford 1968), others have found no relation (Jurkovic 1980; Parrot and Strongman 1984). Past research on delinquency and locus of control relied primarily on the comparison of delinquents and non-delinquents. The groupings of delinquents (usually institutionalized subjects) and nondelinquents are often too gross and may be confounded by unknown factors, and might have made the difference in locus of control less clear or stable. Ross and Mirowsky were among the first to empirically assess a theory of normlessness and powerlessness on adult offending in the field of criminology: they presented an empirical assessment of their theoretical model in 1987 and applied it to a comparative crossnational study of Mexican; Mexican-American and Anglo adults aged 18-65. The study demonstrated independent effects of both normlessness and powerlessness on adult offending.
In 2002, the concept of subjective powerlessness was reintroduced in criminological theory by Colvin, as a mechanism in his coercion theory (Colvin 2002). Coercive control increases external locus of control. The bottom line is that subjective powerlessness / external locus of control is a concept that keeps popping up in criminological theories. It has recently been argued by Wood and Alleyne (2010) that the study of VYG needs to bring in more elements of psychology such as internal processes (cognitions, learned beliefs, ...) that interact with the environment. By reintroducing the learned cognitive belief of subjective powerlessness we attempt to do so in both a theoretical and empirical way.

While a multitude of studies of adolescent offending an violent youth group involvement have focused on the social disorganization / disorder at the neighborhood or census tract level, there is a growing consensus that it is important to study the effect of disorganization/ disorder at the micro-place level, such as the street-level (Wikström and Oberwittler, 2009; Weisburd, Groff and Yang, 2011). In the present study we use the theoretical concept micro-place disorder. We have operationalized micro-places at the streetlevel. The present study thus focuses on micro-place disorder using observational measures of crime and disorder at the street- level.

The structure of this article is as follows: firstly, we give a brief overview of the concept of subjective powerlessness and its evolution. Secondly, we discuss the role of micro-place disorder and subjective powerlessness and subjective powerlessness relationships in an integrated version of alienation theory and in an integrative control model that links micro-place disorder to violent youth group involvement. That is achieved by demonstrating different causal path diagrams that have violent youth group involvement as a dependent variable. Thirdly, we empirically test the integrated model using structural equation models (Muthén and Muthén 2011) and finally we discuss the integrated model.

\section{THE DEVELOPMENT OF THE CONCEPT OF SUBJECTIVE POWERLESSNESS}

According to subjective alienation theory, which emerged in the 1950s subjective powerlessness and normlessness are two types of subjective alienation. During the 1950s, sociology was characterized by a strong interest in the consequences of normlessness and powerlessness. Powerlessness and normlessness 
have been technically defined by Srole (1956) and Seeman (1959). Seeman (1959) was the first to provide a definition for the concept of powerlessness, which he defined as "the expectancy or probability held by the individual that his own behavior cannot determine the occurrence of the outcomes, or reinforcements, he seeks" (1959: 787). A person suffers from alienation in the form of "powerlessness" when he or she is conscious of the gap between what one would like to do and what she or he feels capable of doing. Subjective powerlessness is synonymous of lack of personal control. Subjective powerlessness is the subjective sense of being unable to achieve goals since outcomes are determined by forces external to one's self, such as powerful others, fate, luck, or chance (Ross and Mirowsky 1987). At the one end of the continuum individuals have the feeling of being in control of their own life; while at the other end of the continuum individuals feel that they have no grip of their loves and future. Subjective powerlessness is considered a key factor in the explanation of normlessness. The basic rational behind the theory was that individuals who feel powerless, are likely to give up following general rules about how to morally behave.

The importance of subjective powerlessness is widely recognized within sociology and psychology. The problem is that it has appeared in several forms with various names. That makes it difficult to get an overview of all the studies of the causes and consequences of personal control, as different conceptualizations often lead to different operational measures which may hamper the generalization of findings (Ross and Mirowsky 2003).

In the 1960s subjective powerlessness became a major topic in cognitive psychology (Lefcourt 1982). In cognitive psychology, Rotter (1966) was the first scholar associated with empirical studies of subjective powerlessness. Subsequently, subjective powerlessness re-emerges as "locus of control". Locus of control theorists are interested in between person differences and within-person change in external and internal locus of control. Belief in an external locus of control is a learned, generalized expectation that outcomes of situations are determined by forces external to oneself such as powerful others, luck, fate, or chance. The individual believes that he or she is powerless and incapable of acting upon the environment. Belief in an internal locus of control (the opposite) is a learned, generalized expectation that outcomes are contingent on one's own choices and actions. Compared to persons with an external locus of control, those with an internal locus of control attribute outcomes to themselves rather than to forces outside themselves. Both Rotter (1966) and Seeman (1959) recognized that perceived powerlessness and external locus of control was related concepts. It appears that Rotter admitted that he derived the concept of locus of control from the sociological concept of alienation, stating "the alienated individual feels unable to control his own destiny" (1966:263). ${ }^{3}$

In studies of the sociology of labor and education scholars building their theories on Seeman's original theme of subjective powerlessness started using the label "lack of personal control" in the decades following Seeman's contributions. The term of lack of personal control is closely related to concepts that were used by the early control theorists. It is clear that the concept of subjective powerlessness is a key concept that ties sociology to psychology much in a similar way that Walter Reckless (1961) meant to do with his "personal controls" in containment theory: in that early theory crime is caused by lack of internal and external controls. Reckless probably had something very similar to subjective powerlessness in mind when he discussed the pulls and pushes of juvenile delinquency.

Personal control should be differentiated from similar concepts: it is conceptually different from selfefficacy and it should be differentiated from self-control. Bandura (1986) argued that self-efficacy is the belief in one's own power or ability to produce a specific desired effect, such as staying healthy, quitting smoking, or doing well in school. Bandura relates locus of control to outcome expectancy theory. Bandura argued that selfefficacy is a task-specific construct and not a learned belief, self-efficacy is the individual's belief that he or she can (or cannot) effectively perform a specific action, whereas the sense of control focuses on the belief that one will achieve desired goals.

Finally subjective powerlessness is closely related to, but also quite different from low self-control. Low self-control is seen as a relative stable trait, or a summary construct of individual traits including impulsivity, insensitivity, risk-taking and shortsightedness, that have "a considerable tendency/.../ to come together in the same people, /.../persist through

\footnotetext{
${ }^{3}$ The concept of alienation is multidimensional. Alienation theorists made a distinction between powerlessness (locus of control), meaninglessness, normlessness, isolation and self-estrangement. See Smith and Bohm (2008) for a clear discussion, which goes beyond the scope of this study.
} 
life" (Gottfredson and Hirschi 1990: 90-91) and which are established very early in life. ${ }^{4}$

Throughout this paper, we define subjective powerlessness as a learned, generalized expectation that outcomes are contingent on one's own choices and actions (Mirowsky and Ross 1989; Rotter 1966; Ross, Mirowsky, and Cockerham 1983; Seeman 1983). Subjective powerlessness is the belief that one's actions do not affect outcome. It is the belief that outcomes of situations are determined by forces external to oneself such as powerful others, luck, fate, or chance. As criminologist have been interested with the consequences of fatalism, it seems plausible that the term of subjective powerlessness or external locus of control should be used. The term lack of personal control may be confusing because of its close relation to self-control.

\section{MICRO-PLACE DISORDER, SUBJECTIVE POWERLESSNESS AND VYG: A CONTEMPORARY POWERLESSNESS THEORY OF VYG}

\section{Micro-Place Disorder as a Cause of Subjective Powerlessness and Normlessness}

Ross and Mirowsky (2009) have elaborated on alienation theory and proposed a more general framework which they have named ConditionsCognitions-Emotions Theory (henceforth: CCE theory). Geiss and Ross (1998) and Ross and Mirowsky (1987; 2009) have contributed to the development of CCE theory and have especially focused on the antecedents and consequences of subjective powerlessness and normlessness. Key dependent variables in their studies include distrust and distress (Ross and Mirowsky2001; Ross and Mirowsky 2002; Ross andMirowsky2009). We argue that CCE theory can be considered as an end-to-end elaboration of alienation theory because CCE theory draws on the social disorganization/ disorder tradition and relates neighborhood disorder to subjective powerlessness and normlessness, which in turn have consequences for negative emotions (especially fear, distrust and distress). Seen through the lens of CCE theory, subjective powerlessness and normlessness are important cognitive links between the ecological micro-environment and psychological

\footnotetext{
${ }^{4}$ Gottfredson and Hirschi argued that low self-control is "the primary individual characteristic causing criminal behavior and analogous behavior. We consider low self-control as a contributory cause of violent youth group involvement and do not make such strong claims regarding low self-control being the sole cause of anything. Characteristics such as thrill-seeking may pull youths towards gangs for the sake of the thrill.
}

distress (Mirowskyand Ross2003; Ross, Mirowsky and Pribesh 2001). CCE theory draws heavily on findings from psychological studies of locus of control that have shown that aversive stimuli increase beliefs of fatalism and beliefs of being out of control (Lefcourt 1982). According to CCE theory observations and experiences of disorder may promote distressing views of human nature i.e. negative views that people are by nature malicious and untrustworthy. Disorder signals that the neighborhood social climate is essentially, alienating and beyond personal control. Such arguments about the detrimental effects of neighborhood conditions were also formulated in Skogan's model of disorder, fear and neighborhood dissatisfaction (Skogan1990) for more than a decade ago. But the idea that neighborhood disorder has adverse effects is also a key assumption in contemporary versions of social disorganization theory, which re-emerged since the eighties of previous century (Bursik and Grasmick 1993), especially the collective efficacy framework (see Sampson 2012). Graffiti, noise, vandalism, dirty streets, public drinking, and abandoned buildings are said to be signaling cues. Exposure to such cues reminds neighborhood inhabitants (and visitors) about the dangerous side of world they live in. The strength of the effect of microplace disorder on peoples' lives can be expected to depend on the length of exposure to such adverse micro-place conditions. In short, adverse conditions are indicative of a breakdown of social control and order maintenance. Mirowsky and Ross (2009) build upon observational and cognitive learning mechanisms to explain how adverse micro-place conditions may affect subjective powerlessness and normlessness: it isthrough exposure to threatening social conditions, residents may learn that they are relatively powerless and that normlessness reigns, and therefore they come to mistrust others and remain isolated from them (Diehl and Hay 2010).

\section{Subjective Powerlessness as a Contributory Cause of Normlessness}

In CCE Theory the concept of normlessness refers to the subjective dissociation from socially approved rules that govern behavior combined with the belief that socially unapproved behaviours are valid ways to achieve personal goals in life. This state of normlessness is not an irreversible one but rather a temporary condition of perceived personal breakdown of one's moral attachment to conventional moral rules. The origin of the concept of perceived personal normlessness is derived from the work of Leo Srole (1956) who considered it to be an individual-level 
counterpart of Durkheim's (1893) macro-sociological concept of anomie. Durkheim described anomie as a societal condition, a reality sui generis which he hypothesized to place strong constraints to the behavior of individuals. Perceived normlessness is a concept that is very closely related to legal cynicism, a term that was coined by Sampson and Bartusch (1998). In fact, Sampson and Bartusch empirically demonstrated contextual effects of structural antecedents of neighborhood disorder, namely concentrated disadvantage, to be related to legal cynicism independent of individual background characteristics. In CCE theory a norm is an expectation of how people will behave, and it takes the form of a rule that is socially rather than formally enforced. Legal norms are thus a special case of norms (for similar discussions see also Wikström 2010). Normlessness is the mechanism through which individuals lose their sense of what is right and wrong. The question is how subjective powerlessness increases the likelihood of normlessness. Subjective powerlessness, if installed, temporarily decreases the motivation to conduct efforts to follow the norms of society. Subjective powerlessness stimulates normlessness through processes of individual decision-making to follow the path of least resistance. Subjective powerlessness may stimulate individuals to act according to the principle of least effort and thus no follow the rules of society.

This reasoning reveals a shortcoming in the powerlessness-normlessness- VYG link. The powerless (i.e. adolescents with an external locus of control) are probably not only hampered in their motivation to follow the rules of society. It can also be expected that the powerless will be likely to make less of an effort to exert self-control when the adolescent finds himself / herself in asituation when being tempted or provoked. Indeed, because the powerless doubt their ability to influence events in the future, this belief also affects one's successfulness in exercising delay gratification.

In CCE Theory subjective powerlessness is related to normlessness through learning mechanisms: people learn that they have no grip over their personal lives and therefore are less prepared to pay effort to follow conventional norms. In turn, normlessness can be seen as an important contributory cause of violent youth group involvement. We submit that these theoretical propositions can easily applied to the explanation of individual differences in VYG. As far as we know, no previous study of VYG has tested the core propositions of this model.

A strict application of an integrated micro-place disorder alienation model to the explanation of individual differences in VYG, leads to the logical deduction of following propositions:

$\mathrm{H} 1$ : Micro-place disorder is positively related to subjective powerlessness and normlessness

$\mathrm{H} 2$ : Subjective powerlessness is positively related to normlessness

H3: Normlessness is positively related to VYG

We will refer to this model as the strong version of the theory, which argues that the effect of micro-place disorder on VYG is fully mediated through subjective

The integrative micro-place disorder powerlessness model of VYG involvement

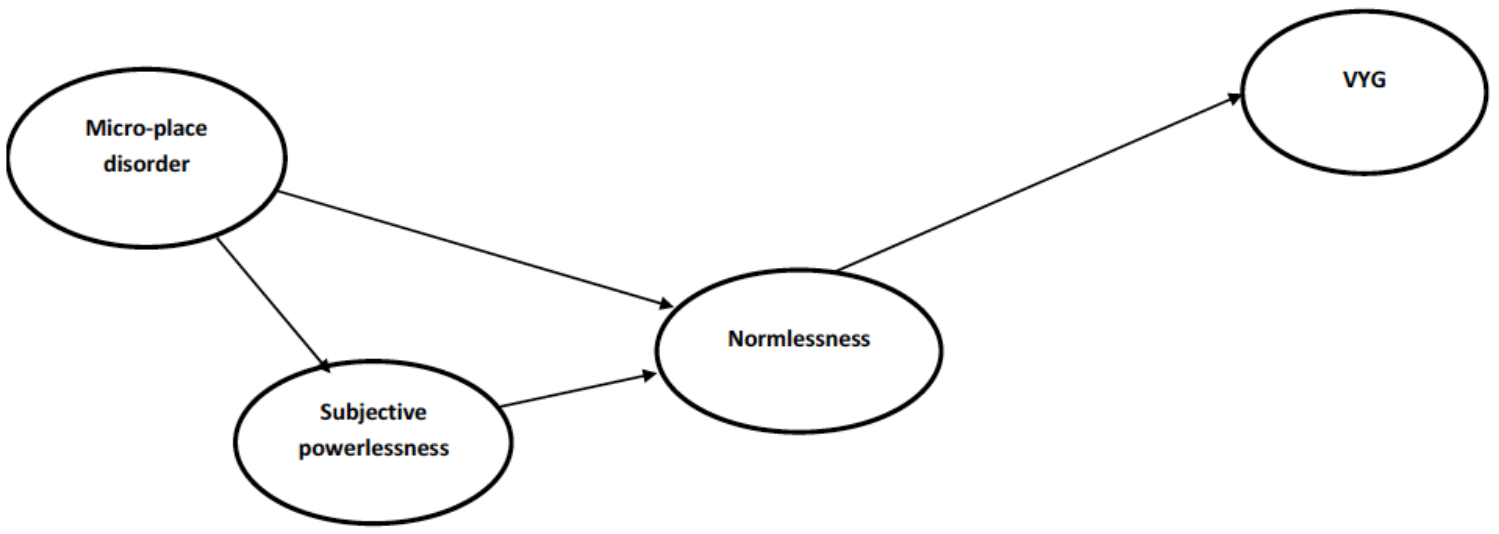

Figure 1: Strict version of micro-place disorder - powerlessness model. 
powerlessness and normlessness $\mathrm{A}$ wide version would allow direct effects of the aforementioned. But that would only suggest that other mechanisms should be included. The integrative micro-place -control model may provide additional mechanisms. This model is discussed in the next paragraph. This model provides an alternative explanation for individual differences in VYG but it will be argued that it has potential for conceptual integration with the micro-place disorderpowerlessness model.

\section{MICRO-PLACE DISORDER, SOCIAL CONTROL, SELF-CONTROL AND VYG: AN INTEGRATIVE CONTROL MODEL OF VYG}

While micro-place disorder plays a role in affecting the likelihood of being involved in a violent youth gang through the temporary installation of subjective powerlessness and normlessness, the integrative micro-place-subjective powerlessness model which is based on CCE theory, does not include a number of mechanisms that contemporary scholars that study gang membership would include in explanations of gang membership. Contemporary (cross-level) integrated theoretical models that have been developed from either the classic or contemporary social disorganization tradition or the neighborhood disorder tradition have identified informal controls (parental monitoring and moral beliefs), self-control, as mediators of the effect of neighborhood disorganization (Bernburg and Thorlindson, 2005; Guterman, et al., 2009; Lynam, 2009; Oberwittler, 2004; Thorlindsson and Bernburg, 2004). In 2007, Vowell presented and tested such an integrated control model (Hence: ICM) of adolescent offending: he called his empirical model the integrative control model. From such a theoretical perspective the neighborhood context was hypothesized to reduce informal social control mechanisms, thus affecting offending primarily through informal social controls. These informal social controls were clearly taken from social bond theory and selfcontrol theory. Vowell (2007) argued that youth residing in disorganized neighborhoods, having weak social bonds, and reporting a lack of self-control should also be more likely to associate with groups having deviant definitions which ultimately led to an increased likelihood of offending. Vowell also stressed the role of peers. The role of peers has traditionally been explained from both social learning theories and unstructured routines/ opportunity theories. In social learning theory peers provide a learning context, while in unstructured routine activity theories peers are considered to be situational instigators. Laub and
Sampson (2003) defended the situational interpretation, mainly due to their criticism of human nature in social learning theories (the blank slate principle) which rendered it less attractive for integrating the role of peers in their age-graded informal control theory. Also Wikström and Sampson (2003) and Wikström and Butterworth (2006) have argued that the social disorganization perspective is compatible with theories that stress the role of unstructured routine-activities (ormore general risky lifestyles) as mechanisms in the explanation of offending (Forde and Kennedy 1997; Maxfield 1987; Wikström and Butterworth 2006). The main reason is that the frameworks of social disorganization, social control, self-control and the routine-activity theory of general offending (RATG) share highly compatible visions of human nature and social order (Lilly, Cullen and Ball 2010). These models leave room for agency. ${ }^{5}$ Wikström and Butterworth used the concept of lifestyle risk and argued that lifestyle risk is a more general ('overall') concept that reflects exposure to criminogenic moral settings either through unstructured routines or the presence of peers. Based on these ideas outlined in Wikström and Butterworth (2006), some scholars have proposed and tested an end-toend integrative control model that incorporated the concept of lifestyle risk to explain individual differences in violent youth group involvement (Pauwels 2010; Pauwels and Svensson 2013). In fact, this study elaborates on these previous studies.

In line with recent developments in environmental criminology, we study the effects of micro-place disorder using observational measures of street-level disorder. This way of theorizing and analyzing does not conflict with neighborhood theories of disorganization and disorder. ${ }^{6}$

\footnotetext{
${ }^{5}$ Conceptual integration has long been conducted from the basic idea that the original theories that were to be integrated should be compatible and share common visions of human nature, social order and crime. Agnew has recently demonstrated that human nature is far more complex than each of the classic theoretical frameworks stressed. Man is not just selfish, but both selfish and altruistic. Man is no blank slate but born with his or her genetic make-up which somewhat constrains individuals' agency. That is not deterministic, that is just a fact that has arisen from biosocial criminology and the contemporary neurosciences. Human nature and causation do not operate in a deterministic way. Only scholars have interpreted theories in a deterministic or probabilistic way. We follow philosopher of science Mario Bunge who argued that causal determination is just one form of determination and that auto-determination is as important as causal determination. In Bunge's view causation is productive: it generates an effect through the operation of mechanisms with certain likelihood. Causation is as probabilistic in social sciences as it is in the microworld of quantum physics.

${ }^{6}$ We submit that there is no conflict as we consider disorder is both an outcome of low collective efficacy and a outcome of social disorganization. The nature of the relationship between disorder, disorganization and crime is beyond the scope of the present study (see Sampson 2012 for a discussion of the complexity of this relationship).
} 




Figure 2: Strict version of an integrative micro-place disorder - control model.

\section{Integrating Subjective Powerlessness in an} Integrative Control Model of VYG

Growing up in disorderly micro-settings may have consequences for subjective powerlessness and parental monitoring. Building on Mirowsky and Ross (2003), we argue that (1) the presence of social disorder in micro-settings may promote the view that people are by nature untrustworthy, and unhelpful, that life is alienating and beyond personal control and (2) that the presence of counter-narratives (e.g. subcultural values) may promote the view that law-abiding is futile and deterrence is non-existing. Micro-place disorder may also start a negative "causal chain" by decreasing parental monitoring and installing subjective powerlessness in youths. Consequently these characteristics shape (through learning principles) beliefs that normlessness rules.

In short, the development of the fatalistic belief that one is not in charge of one's own life should be considered as an additional mechanism that may have consequences for VYG involvement in several ways in the integrated theory:

- (1) Subjective powerlessness makes it difficult for youths to personally invest in conventional moral standards, which are of less use in a world that is perceived to be driven by fate. Subjective powerlessness promotes the temporary installation of normlessness. Living by conventional moral standards pays off in the long run, but that makes less sense to subjective powerlessness youths as they are not guided by a belief that they can control the outcome of their action and thus their future;

- (2) subjective powerlessness is a belief that challenges the establishment and maintenance of self-control as it promotes an orientation towards the present instead of towards delayed gratification.

Individuals who share the belief that they are not in control of the future instead concentrate on the present, on oneself, and put less effort into controlling their temper. And makes one less resistant to withstand thrill-seeking behavior.

\section{The Role of Self-Control and Lifestyle Risk}

Individuals who possess low self-control are more likely to become involved in criminal, deviant, and accidental behaviors than those who possess high levels of self-control. Gottfredson and Hirschi (1990) consider the relationship between violent youth group involvement and offending as a spurious relation as low self-control would be the common cause. However, 
empirical studies show that self-control is not the only necessary condition leading to criminality (Pratt and Cullen 2000).

Routine activity theory (Bernasco et al. 2013; Felsonand Boba, 2010) argues that delinquency results, in part, from individuals' spending time in situations that offer appealing opportunities for that behavior. This perspective finds support in evidence that many problem behaviors are associated with spending time in unstructured and unsupervised socializing with peers (e.g. Higgings and Jennings 2010; Haynieand Osgood, 2005; Osgood et al., 1996).

When an individual becomes habituated to the street-corner lifestyle, the chances of his or her becoming affiliated with violent youth groups are further increased. The street-corner lifestyle is characterized by unstructured socializing with peers that one considers to be similar to one, living on the edge, being involved in exciting unstructured routine activities day by day, unhindered by feelings of future responsibilities, which have primarily been neutralized by lowered levels of personal control, weak social bonds, and perceived normlessness. Lifestyles were originally considered of importance as a causal mechanism in the explanation of victimization, while more some recent studies actually suggest that lifestyles are of much more importance in explaining individual differences in offending (Wikström and Butterworth) 2006. When an individual becomes habituated to the street-corner lifestyle, the chances of his or her becoming affiliated with violent youth groups are further increased.

The above presented mechanisms have been discussed in the still-nascent empirical literature on covariates of VYG (Alleyne and Wood 2010; Curry, Decker and Pyrooz 2003; Esbensen et al. 2010; Katz and Fox, 2010; Sharp, Aldridge, and Medina 2006; Thornberry et al. 2003). The key mechanisms involved in the integrated micro-place disorder-powerlessnesscontrol theory are observed micro-place disorder, subjective powerlessness, parental control, normlessness, low self-control and lifestyle risk.

The fully integrated micro-place disorderpowerlessness-control model is visualized in Figure 3.

Six testable hypotheses are central to the integrative micro-place disorder-powerlessness-control model.

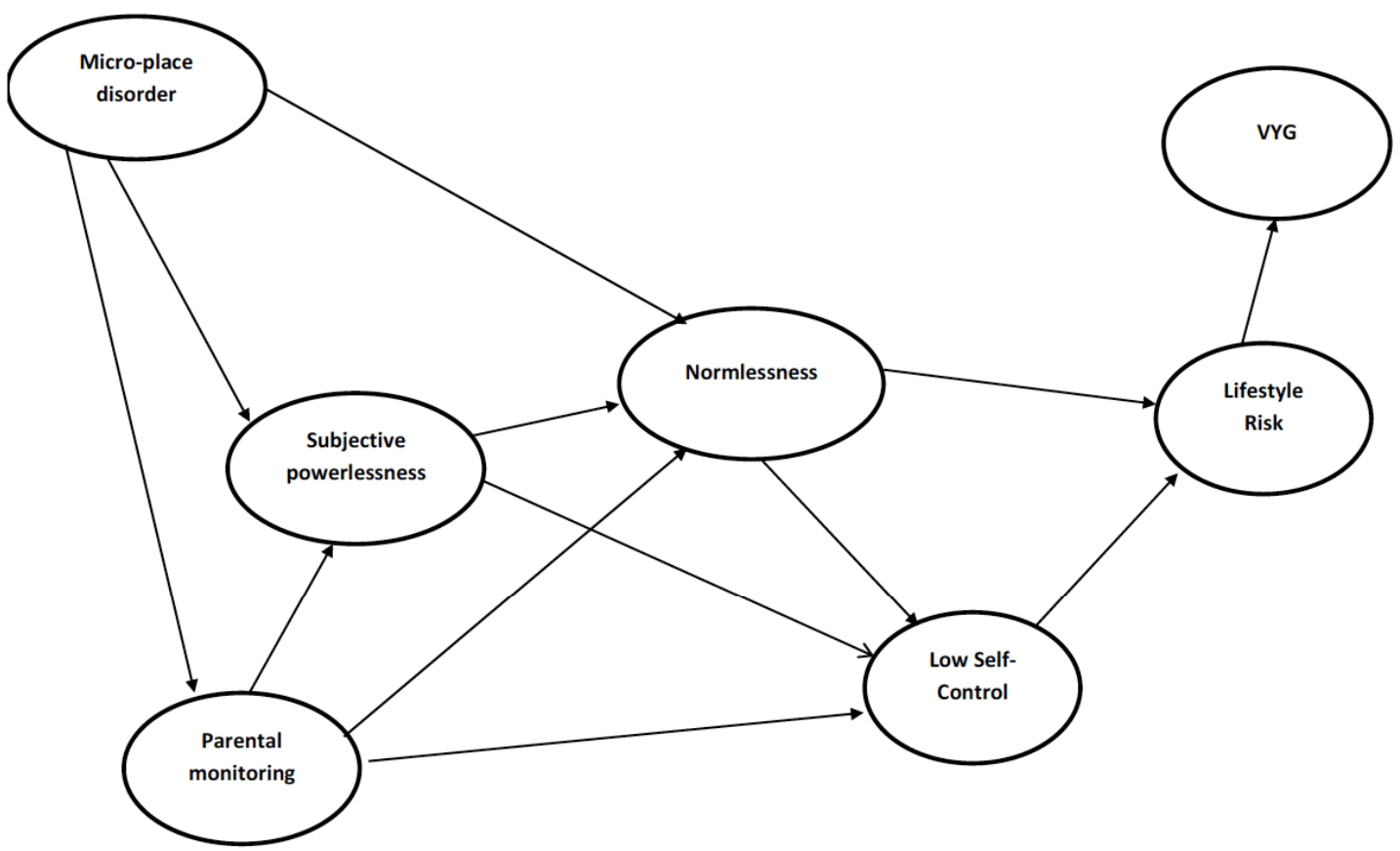

Figure 3: Hypothesized model of subjective powerlessness in an integrative control model of VYG. 
H1: The effect of observed micro-place disorder on violent youth group involvement is fully indirect. Observed micro-place disorder is negatively related to parental control and positively related to subjective powerlessness and normlessness.

H2: Subjective powerlessness is positively related to normlessness and positively related to low self-control and thus only indirectly related to violent youth group involvement.

H3: Parental control is negatively related to subjective powerlessness, normlessness and low self-control.

H4: Normlessness is positively related to low selfcontrol and lifestyle risk.

H5: Low self-control is positively related to lifestyle risk.

H6: Lifestyle risk is positively related to violent youth group involvement.

\section{DATA AND METHOD}

\section{Participants}

The Antwerp Youth Survey is a school survey consisting of 2,486 young adolescents in 23 schools (effective sample size) and 42 neighborhood clusters (= all neighborhood clusters of Antwerp) in the first cycle of the Belgian secondary school system. The first cycle of the Belgian secondary school system is compulsory and corresponds to grade 7 and 8 in the US school system. The sample frame consisted of youths in early adolescence that lived and went to school in Antwerp neighborhoods. The average grade 7 student is 13 years old and the average grade 8 student is 14 years old. This sample frame was chosen for several reasons: a disproportional number of youth studies on adolescent offending focuses on midadolescence. The main reason cited in the literature for this historical disproportional overrepresentation of youth in mid-adolescence is the well-documented age crime curve, which produces on the aggregate level higher proportions of youths reporting offending and violent youth group involvement. However, the early adolescent years (11-14 years of age) are a crucial time when youths are exposed to gangs and may consider joining a gang. Some gang research clearly shows that the average age when adolescents join gangs is 14 years old (Pyrooz, Sweeten and Piquero 2014; Pyrooz 2014). From a developmental life course perspective it is stressed and well-documented that risk factors of offending and violent youth group involvement vary at different stages of development. In Belgium the absence of criminological enquiries that focus on early adolescence is striking and has been criticized before (Pauwels, Hardyns and VandeVelde, 2010). The Antwerp Youth Survey was a first attempt to fill the gap of studies of crime causation in a country where criminology as a discipline had no strong tradition in the etiology of adolescent offending and violent youth group offending. The study was especially designed to test competing and compatible theories of adolescent offending and violent youth group involvement. The study design was a cross-nested sample of individuals in schools and neighborhoods. The respondents lived and went to school in Antwerp, the second largest city in Belgium. Antwerp (including its suburbs) has approximately 502,000 inhabitants. The response rate was $92.5 .5 \%$ of the students in the participating schools. The Antwerp survey consisted of $49.4 \%$ boys and $50.6 \%$ girls. Almost half of the respondents had a fully native background (both parents from Belgian descent), ten percent of the respondents had one parent with an immigrant background, while $45.5 \%$ of the respondents had two parents with an immigrant background. The overrepresentation of immigrants is partially due to a higher participation of schools in inner-city areas. Although all schools of the first grade were contacted, only $33.3 \%$ of all schools participated. Of course, this issue raises concerns regarding the external validity of the results. As the sample was drawn from a nonrandom selection of schools in Antwerp, it is not a representative sample of Belgian youth, but it is highly varied in terms of ethnic background and education. However, we detected no pattern in refusals to participate. We evaluated the extent to which this sample is representative at least at the neighborhood level. Following Oberwittler (2004) a comparison between aggregate survey-based demographics and aggregate census-tract data revealed quite high correlations between both survey-based and census data based measures of demographic background characteristics. The neighborhood-level correlation between the percentage of adolescents with at least one parent with an immigrant background (from outside the EU anno 2007) and the percentage of inhabitants from Morocco and Turkey (census data-based indicator) was 0.818 ( $p>0.001)$, and the neighborhoodlevel correlation between the concentration of family disadvantage (survey-based information) and a measure of neighborhood disadvantage (administrative data) was 0.581 ( $p<0.001)$. For more details we refer to the original study and additional articles (Pauwels 
2012; Pauwels 2013).Almost three quarters of the respondents were aged 12 to 14 years, while $26.2 \%$ of the respondents were aged 15 to 16 years. ${ }^{7}$ Fifteen percent of the respondents lived in a single parent/caregiver family, and $85 \%$ of the respondents lived with two parents or caregivers.

\section{Measures}

\section{Micro-Place Disorder (DISORD)}

Micro-place disorder is measured using observational measures of street-level disorder: a combined index of ten situations that may be observed very nearby ("street" definition ${ }^{8}$ ) the respondents' residences. ${ }^{9}$ The respondents were asked how many times they observed ten disorderly events on a four point scale (never, sometimes, often, very often). The following items were the listed events: Neighborhood inhabitants quarrelling on the street; older people being angry with youth; Someone trying to hide something in a shopping bag in a local store to steal it; garbage and/or dirt being on the sidewalk; a group of local youth harassing someone to get money or something else of value; House fronts, doors, etc. being covered with graffiti; a couple of men drinking alcohol (beer, etc.) in the street (e.g.: at a bus-stop or local supermarket); Someone selling drugs (hash, marijuana, etc.) on the streets; someone being threatened with a weapon on the street (fire arm, knife, etc.); youth starting a fight because he or she was challenged by other youth. High values on this measure indicate high levels of perceived disorder. Alpha was 0.84. Detailed information on the index and the wording of the items is provided in Appendix 1.

\section{Subjective Powerlessness (SPOW)}

Subjective powerlessness was measured using the "subjective powerlessness for adolescents"-scale. The

\footnotetext{
${ }^{7}$ From a life-course developmental approach one could argue to omit the 15-16 year old students. The vast majority of these students were 15 years old. The processes that are studies are however expected to be found in every age group. In fact, we ran analyses by subgroup and we did not detect any significant difference.

${ }^{8}$ If respondents mentioned they lived in a very large street, we used the alternative "five-minute walk" definition. Although we use observational questions, all observation of the environment goes through perception, i.e. our senses. However, these observations do not come out of the blue but are strongly related to the events happening (Wikström et al. 2012).

${ }^{9}$ Wikström and Sampson (2003) have further argued that the study of neighborhood effects such as the effects of disorganization and disorder may benefit from a reconceptualization of neighborhoods as activity fields. The activity field is a small part of the environment that can be perceived by our senses (Wikström et al. 2012). Large geographical areas can therefore not be considered as part of the individual's activity field. Some ecological units of analysis are simply too heterogeneous to be potential candidates for serving as a behavioral setting. Sizes and boundaries are thus key issues in the study of neighborhood effects.
}

scale has been previously used in Belgian studies of educational sociology and school contextual effects (Brutsaert 2001). There are similarities and differences between the measure used in the present study and Mirowsky and Ross' measurement. Subjective powerlessness was measured by three items that reflected the belief that personal action does not lead to results: "working hard is useless, it seldom pays off for me", "I often have the feeling I end up in trouble beyond my own control" and "I believe that planning does not lead to success". Our justification for the use of this scale lies in the fact that these items reflect the fatalism that was discussed in early gang studies. Contrary to Mirowsky and Ross who used items that measures both external and internal locus of control, we only included items that external locus of control. In psychology and sociology numerous scales exist. These scales usually refer to specific dimensions (work, school, ...). Our choice for the scale developed in educational sociology lies in the fact that is was exclusively developed for adolescents. High values on this measure indicate low levels of personal control. Alpha was 0.58 . The alpha value was somewhat lower than the alpha values of the other constructs, but factor analysis revealed that all items had sufficiently large factor loadings on a single factor (all loadings $>0.50$ ). It is important to stress that there were no cross-loadings of subjective powerlessness items on other measures (e.g. low self-control and normlessness). A crossloading means that an indicator has sufficiently high factor loadings on more than one concept (e.g. an $X$ and $Y$ variable). If that would have been the case, our measure would be biased and a tautology problem could have arisen. Indicators should be unbiased indicators and refer to only one latent concept. There is clearly conceptual differentiation. ${ }^{10}$

\section{Parental Monitoring (MONITOR)}

Parental control (monitoring) was measured by five items with an Alpha level of 0.709 . High values on this measure indicate high levels of monitoring. The items used were: "My parents know whom I hang around with when I am not at home", "My parents know where I am when I am not at home", "My parents know how I behave when not at home", "When I have to go to school the next day, I need to be in bed on time", "If I am with friends, I need to be home at an agreed hour".

\footnotetext{
${ }^{10}$ Cross-loadings were tested using confirmatory factor analyses. All items load on one construct, modification indices did not show any aberrations between the subjective powerlessness-items and the self-control and normlessness items.
} 
The scale has been used in different studies on different populations (Pauwels and Svensson 2013; Pauwels 2013).

\section{Normlessness (NORM)}

Normlessnessis measured using a scale that contains items that are taken from Sampson and Bartush's (1998) legal cynicism scale. The scale is an additive index consisting of the following items: "Rules are made to be broken", "It is OK to break rules, as long as one does not get caught", "It is OK to fight, when one is provoked", and "If honest ways to achieve something fail, and then it is OK to use dishonest ways". Cronbach's $\alpha$ is 0.80 . High scores refer to high levels of normlessness. 0.778 .

\section{Low Self-Control (LSC)}

Low self-control is an additive index mainly based on the items used and developed by Grasmick, Tittle, Bursik, and Arneklev (1993). This scale measured whether an individual had difficulties resisting temptation and provocation. High values on this measure indicate low self-control. Seven items were included, and Alpha was 0.782. Following items were used: "I often do things without thinking first", "I have fun whenever I can, even if I get into trouble afterwards", "I say what I think, even if it's not smart", "I often do what I want to do", "When I am angry, others had better stay away from me", "When I am angry, l'd rather hit than talk", "I am able to quietly discuss quarrels". The first three items measure impulsivity and the other items measure temper (anger-identity).

\section{Lifestyle Risk (LIFESTYLE)}

Lifestyle risk was measured as a combined index of unstructured routines (how often adolescents hung out in the city center, on street corners or parks) Cronbach's Alpha for the unstructured routine risk scale was 0.70 , and for the peer delinquency scale 0.81 ). The overall measure was a combined risk score summing the risk, balanced and protective ends of the distribution of each construct (Wikström and Butterworth 2006; Svensson and Pauwels 2010). We refer to the appendix for details.

\section{VYG Involvement (VYG)}

VYG involvement was measured using a funneling technique, i.e., we combined answers to one filter question and five follow-up questions to measure selfreported VYG. The leading question was, "Some adolescents have a steady group of friends to do things together, or to hang around outside. Do you have such a group of friends?" ( 1 = yes, $0=n o$ ). The five followup questions were (1) "Are the members of this group involved in fights and quarrels with other adolescents?" (2) "Do members of this group act before talking when the group's image is at stake?" (3) "Are there some members of this group prepared to do dangerous and exciting things?" (4) "Are members of this group involved in fights with other cliques?" (5) "Are members of this group involved in law-breaking?" These followup items were originally presented on a four-point scale $(0=$ never, $1=$ sometimes, $2=$ often, $3=$ very often $)$ but were dichotomized $(1=$ yes, $0=n o$ ). Respondents were categorized as involved in a violent youth group if they

Table 1: Descriptives

\begin{tabular}{|c|c|c|c|c|c|}
\hline & $\mathbf{N}$ & Min & Max & Mean & Std \\
\hline Gender & 2485 & 0.00 & 1.00 & 0.49 & 0.50 \\
\hline Parental control & 2454 & 5.00 & 25.00 & 19.58 & 4.37 \\
\hline Normlessness & 2461 & 4.00 & 20.00 & 9.94 & 4.35 \\
\hline Micro-place disorder & 2443 & 0.00 & 29.00 & 7.48 & 5.36 \\
\hline Routine risk index & 2410 & -1.00 & 1.00 & -0.53 & 1.31 \\
\hline Impulsiveness & 2394 & 4.00 & 20.00 & 12.58 & 3.96 \\
\hline Temper & 2403 & 3.00 & 15.00 & 8.59 & 3.24 \\
\hline Lifestyle risk & 2382 & -3.00 & 3.00 & -1.47 & 1.32 \\
\hline VYG & 2476 & 0 & 1 & 0.08 & 0.27 \\
\hline Low self-control & 2375 & 7.00 & 35.00 & 21.18 & 6.32 \\
\hline Subjective powerlessness & 2400 & 3.00 & 15.00 & 8.31 & 3.01 \\
\hline Immigrant background & 2486 & 0.00 & 10.00 & 0.45 & 0.49 \\
\hline Valid N (listwise) & 2172 & & & & \\
\hline
\end{tabular}


answered affirmatively to the leading question as well as the five follow-up questions. ${ }^{11}$ Our measure cannot be compared to U.S. studies that measure gang membership, but is borrowed from a study of Heitmeyer and very resembling to a previous (2005) version of the Eurogang working group questionnaire, which has been successfully used in many studies on troublesome youth group involvement (Decker and Weerman, 2005; Gatti et al., 2010). For the descriptive values of the all the variables included in the analysis, see Table 1.

\section{Analysis Plan}

Structural equation modeling (SEM) for continuous and dichotomous variables was used to test the paths between the exogenous and endogenous variables. All analyses were conducted using Mplus, version 7.12 (Muthén and Muthén, 2011). Structural equation models are considered common extensions of the linear path model (JöreskogandSörbom1993; Bollen1998). Path models, which combine dichotomous outcomes (such as VYG involvement) or count data (such as counts of offenses), with exogenous continuous variables can be handled with Mplus (Byrne 2011). Mplus also allows for adjusting the standard errors. Respondents are clustered in neighborhoods and schools. This complex cross-classified clustering is possible in Mplus 7.0. In this case, standard errors for clustered data are used. Micro-place disorder refers to the street-level. Therefore micro-place disorder was not aggregated at the street-level and could not be treated like a level-two variable. We did not do so, because of the fact that our sample did not yield enough respondents per street. ${ }^{12}$ All scale scores were standardized before entering the equation. SEM allows for testing of direct and indirect effects that are derived from theories and in that sense, they only provide a statistical test of hypothesized relationships between mechanisms. The role of theory is to discover mechanisms that help us understand how structure,

\footnotetext{
${ }^{11}$ To the introductory question $(n=894), 36 \%$ of the total sample positively, $27.8 \%$ answered positively to the first follow-up question; $18.3 \%$ answered positively to the second follow-up question; $21.2 \%$ answered positively to the third follow-up question; $27.8 \%$ answered positively to the fourth follow-up question; and $20.4 \%$ answered affirmatively to the fifth follow-up question. Only $8.1 \%$ responded positively to the leading and all follow-up questions.

${ }^{12}$ In a previous study based on this sample multilevel modelling was used to study the effects of neighborhood clusters on self-reported offending, however, all neighborhood differences were due to individual demographic characteristics (gender and immigrant background). We found that 98 per cent of the respondents did not live in the same street. Those that lived in the same street lived sufficiently far away from each other. Therefore we felt that it did not make sense from a theoretical standpoint to treat such respondents as living in the same micro-place. The reader should think of such streets as avenues that continued in several zip-code areas.
}

processes and agency are intertwined. It should be stressed that, no matter how powerful statistical techniques such as SEM are, they can never demonstrate causality. In that sense the use of statistics is just a toolkit, which gives some guidelines that can be used to evaluate hypothesized relationships between variables that are supposed to represent mechanisms. Thus SEM is highly suitable to evaluate our previously made statements of direct and indirect effects of micro-place disorder and subjective powerlessness. Model fit indices such as RMSEA and $\mathrm{CFI}$ are used together with to the more traditional $r$ square to evaluate the hypotheses and explanatory power. ${ }^{13}$ We bear in mind that cross-sectional data are far from ideal to test such relationships and were therefore extremely careful when interpreting the result. Unfortunately no panel study of self-reported offending and VYG has ever taken place in Belgium. For reasons of parsimony only the best fitting models are presented. All effects have reached statistical significance ( $p$ $<0.01$ ). A calculation of total effects is not done as the dependent variable is a dichotomy and the test of direct and total effects in combined linear and nonlinear models is still problematic (Byrne 2011).

\section{RESULTS OF PATH ANALYSES}

\section{The Integrated Micro-Place Disorder-Power- lessness Model of VYG}

Table $\mathbf{2}$ and Figure $\mathbf{4}$ summarize the results of a test of the micro-place disorder-powerlessness model. There was a direct effect of micro-place disorder on subjective powerlessness $(\beta=0.24)$ and normlessness $(\beta=0.137)$. This is exactly was the conditionscognitions-emotions theory of Mirowsky and Ross predicts. However, there still is a direct effect of microplace disorder on VYG (log-odds: 0.29). Further we observed a direct effect of subjective powerlessness on normlessness $(\beta=0.38)$ and a direct effect of normlessness on VYG $(\beta=0.53)$. The model fit is highly acceptable (RMSEA: 0.02; CFI: 0.99 ). About $6 \%$ of the variance in subjective powerlessness can be explained by micro-place disorder. That is not much, indicating that there may be many additional sources of subjective powerlessness that were not taken into account. About $23 \%$ of the variance in normlessness can be explained by micro-place disorder and subjective powerlessness. That is in line with the

\footnotetext{
${ }^{13}$ The RMSEA fit index should preferably have a value below 0.05 while the CFI index should have a value above 0.96 (Bollen 1996).
} 
Table 2: Direct Effects of the Integrated Micro-Place Disorder-Powerlessness Model of VYG

\begin{tabular}{|c|c|c|c|}
\hline \multirow{2}{*}{ Independent variables* $^{*}$} & Subjective powerlessness & Normlessness & VYG \\
\cline { 2 - 4 } & $\boldsymbol{\beta}$ & $\boldsymbol{\beta}$ & 0.20 \\
\hline \hline Micro-place disorder & 0.24 & 0.38 & -29 \\
\hline Subjective powerlessness & -- & & 0.53 \\
\hline Normlessness & & 0.231 & 0.384 \\
\hline R-square & 0.061 & & 0. \\
\hline
\end{tabular}

Model fit: RMSEA: $0.02 \mathrm{CFI}: 0.99$

${ }^{*}$ All effects are standardized beta coefficients, except for the direct effect on VYG, these are log-odds, as VYG is a dichotomous outcome.

The integrative micro-place disorder- powerlessness- model of VYG involvement

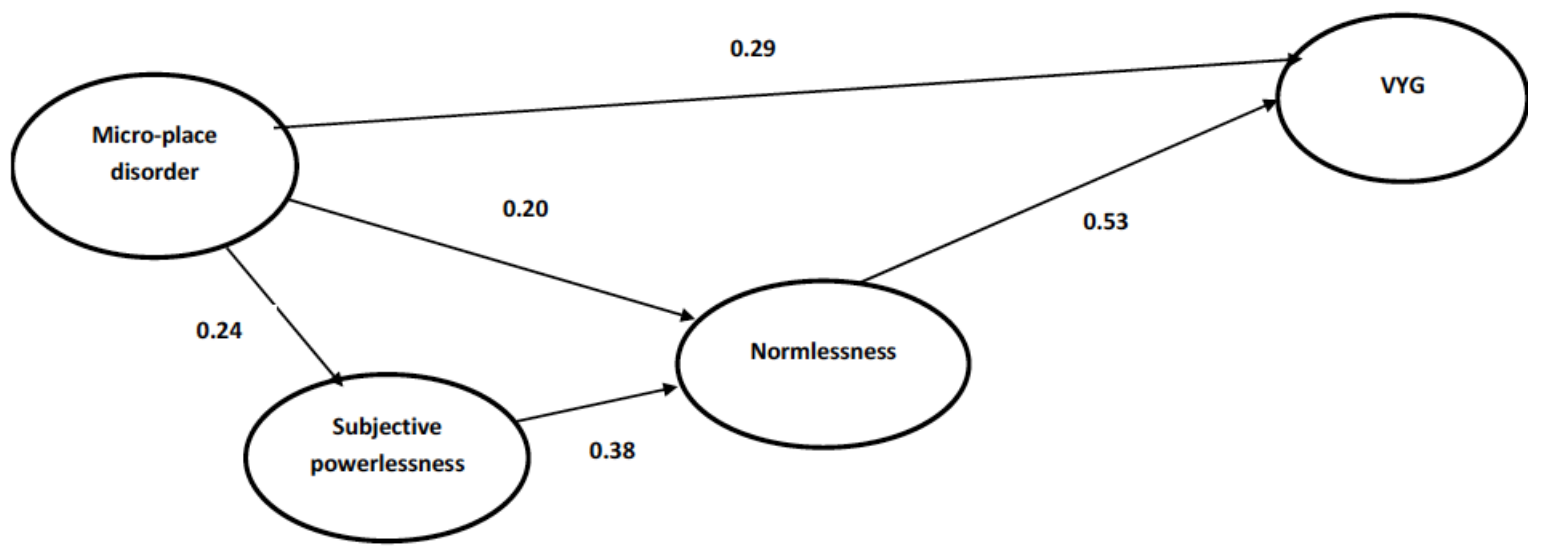

Figure 4: The integrative micro-place-disorder-powerlessness model.

theory. The remaining direct effect of micro-place disorder suggests that other mechanisms should be taken into account. The pseudo R-square of VYG is 0.38 per cent. Before evaluating the fully integrated model we turn on to the integrative micro-place disorder-control model. It is important to know the model fit and effect parameters of the alternative integrative model before one can evaluate the fully integrated model that incorporates subjective powerlessness. That is an additional test of the usefulness of a fully integrated model. If the model fit does not improve, one can argue from the principle of parsimony that the explanation of VYG does not require the elaboration that we propose.

\section{The Integrated Micro-Place Disorder-Control Model of VYG}

Table 3 presents the results of the best fitting model derived from the integrative micro-place disordercontrol model. The results are additionally visualized in Figure 5.
There was a direct effect of micro-place disorder on parental monitoring $(\beta=-0.25)$, normlessness $(\beta=0.20)$, low self-control $(\beta=0.16)$, lifestyle risk $(\beta=0.33)$ and VYG (log-odds=0.18). These direct effects are in line with the integrative control model. However, the remaining direct effect of micro-place disorder suggests that the strong version of the theory which assumed full mediation does not hold. Let us now turn to the effects of parental monitoring. This variable has direct effect on normlessness ( $\beta=-0.36$ ), and low self-control $(\beta=$ $0.08)$. There are no direct effects of monitoring on lifestyle risk and VG, suggesting full mediation via normlessness and low self-control. Normlessness has a direct effect on low self-control $(\beta=0.51)$, lifestyle risk $(\beta=0.28)$ and VYG (log odds $=0.38)$. Low selfcontrol has a direct effect on lifestyle risk $(\beta=0.20)$, and has no direct effect on VYG. Lifestyle risk has a direct effect on VYG (log odds $=0.20)$ and acts as a full mediator of low self-control in our study.

Finally we evaluate the model fit. This model has an acceptable fit (RMSEA: 0.05 and CFI: 0.99). Six per 
Table 3: Direct Effects of the Integrative Micro-Place Disorder-Control Model of VYG

\begin{tabular}{|c|c|c|c|c|c|}
\hline \multirow{2}{*}{$\begin{array}{c}\text { Independent } \\
\text { variables }\end{array}$} & Parental monitoring & Normlessness & Low self-control & Lifestyle risk & VYG \\
\cline { 2 - 6 } & $\boldsymbol{\beta}$ & $\boldsymbol{\beta}$ & $\boldsymbol{\beta}$ & Log Odds \\
\hline \hline Micro-place disorder & -0.25 & 0.20 & 0.16 & -- & 0.18 \\
\hline Parental monitoring & -- & -0.36 & -0.08 & 0.51 & - \\
\hline Normlessness & -- & -- & 0.38 \\
\hline Low self-control & -- & -- & -- & -- \\
\hline Lifestyle risk & -- & -- & 0.38 & 0.20 \\
\hline R-square & 0.06 & 0.22 & 0.35 & 0.46 \\
\hline
\end{tabular}

Model fit: RMSEA: 0.05 CFI: 0.99

${ }^{*}$ All effects are standardized beta coefficients, except for the direct effect on VYG, these are log-odds, as VYG is a dichotomous outcome.

Integrative micro-place disorder-control model of VYG involvement



Figure 5: Direct effects of the integrative micro-place disorder-control modelof VYG.

cent of the variance in parental monitoring can be explained by micro-place disorder. The explained variation for normlessness is 22 per cent. This is acceptable, if one takes into account that only two variables are part of the equation. The explained variation for low self-control is 38 per cent. The unique contribution of parental monitoring is statistically significant but weak; suggesting that parental control by and large operates through normlessness. The explained variation for lifestyle risk is 22 per cent. The pseudo- $R$ square for VYG is 46 per cent.

\section{The Fully Integrated Micro-Place Disorder- Subjective Powerlessness- Control Model of VYG}

Table 4 presents the direct effects that were identified in the fully integrated model. We present the best fitting model. In this section, we confront the hypothesized model directly with the best fitting model. This means that we discuss the direct effects, i.e. the effect relations ("causal arrows") that are drawn in the integrative model. There is a direct effect of microplace disorder on subjective powerlessness $(\beta=0.20)$, parental monitoring $(\beta=-0.25)$, normlessness $(\beta=0.14)$, low self-control $(\beta=0.14)$. The direct effect of microplace disorder on VYG has vanished. The results suggest that subjective powerlessness acts as a mediator for the effect of micro-place disorder on VYG. Traditional models of micro-place disorder on VYG have as far as we know not investigated this link. Of equally importance to evaluate the role of subjective powerlessness is the study of the effects of subjective powerlessness on normlessness and low self-control. 
Table 4: Direct Effects of the Fully Integrative Model of VYG

\begin{tabular}{|c|c|c|c|c|c|c|}
\hline $\begin{array}{c}\text { Independent } \\
\text { Variables* }\end{array}$ & $\begin{array}{c}\text { Parental } \\
\text { Monitoring }\end{array}$ & $\begin{array}{c}\text { Subjective } \\
\text { Powerlessness }\end{array}$ & Normlessness & Low Self-Control & $\begin{array}{l}\text { Lifestyle } \\
\text { Risk }\end{array}$ & VYG \\
\hline & $\beta$ & $\beta$ & $\beta$ & $\beta$ & $\beta$ & Log Odds \\
\hline Micro-place disorder & -0.25 & 0.20 & 0.14 & 0.14 & 0.33 & -- \\
\hline Parental monitoring & -- & -0.18 & -0.32 & -- & -0.27 & -- \\
\hline $\begin{array}{c}\text { Subjective } \\
\text { powerlessness }\end{array}$ & -- & -- & 0.13 & 0.29 & -- & -- \\
\hline Normlessness & -- & -- & -- & 0.42 & 0.29 & 0.79 \\
\hline Low self-control & -- & -- & -- & -- & 0.19 & -- \\
\hline Lifestyle risk & -- & -- & -- & -- & -- & 0.52 \\
\hline R-square & 0.06 & 0.09 & 0.32 & 0.46 & 0.35 & 0.47 \\
\hline
\end{tabular}

Model fit: RMSEA: $0.03 \mathrm{CFI}: 0.99$.

${ }^{*}$ All effects are standardized beta coefficients, except for the directs effect on VYG, these are log-odds, as VYG is a dichotomous outcome.



Figure 6: Direct effects of integrative micro-place disorder- subjective powerlessness-control model of VYG.

Recall that the link existed in the first model, but that model did not take parental monitoring into account. Subjective powerlessness had two direct effects: a direct effect on normlessness $(\beta=0.13)$ and low selfcontrol $(\beta=0.29)$. There are no direct effects between subjective powerlessness and lifestyle risk and between subjective powerlessness and VYG. This effect of subjective powerlessness on VYG is thus fully mediated. This confirms the hypothesis that subjective powerlessness only has an indirect effect on VYG. While the effect of subjective powerlessness on normlessness is in the right direction, it is a not strong effect. Parental monitoring had multiple direct effects: we observed a direct effect on subjective powerlessness $(\beta=-0.18)$, normlessness $(\beta=-0.32)$, lifestyle risk $(\beta=-0.27)$. The effect of parental monitoring on low self-control was entirely mediated by subjective powerlessness and normlessness. Recall that the integrated control model that ignored subjective powerlessness still revealed a direct effect of parental monitoring on low self-control. Our findings thus suggest that the effect of parental control on selfcontrol is fully mediated through subjective powerlessness and normlessness.

Normlessness has multiple direct effects: we observed a direct effect on lifestyle risk $(\beta=0.29)$, low self-control $(\beta=0.42)$ and VYG (log odds $=0.789)$. 
There is a direct effect of low self-control on lifestyle-risk $(\beta=0.19)$ but not on violent youth group involvement. This effect is fully mediated through lifestyle risk. There is no direct effect of low self-control when lifestyle risk is taken into account. It is through the emergence of a risky lifestyle that low self-control brings about an increased likelihood of being in a violent youth group. Contrary to what we hypothesized, the effect of normlessness is not fully mediated. That means that research should reflect on other mechanisms that can account for the direct effect of normlessness.

The model fit is highly acceptable (RMSEA: 0.03 and CFI: 0.99), thereby suggesting that the model fits the observed data rather well. About 6 per cent of parental monitoring is explained by micro-place disorder. Regarding subjective powerlessness we observe that 9 per cent of the variance could be explained by micro-place disorder and parental monitoring. About 32 per cent of the variance in normlessness is explained by micro-place disorder and parental monitoring and subjective powerlessness. About 46 per cent of the variance in low self-control is explained by micro-place disorder, subjective powerlessness and normlessness. 35 per cent of the variance in lifestyle risk was explained by micro-place disorder, normlessness and low self-control. The pseudo-r square of VYG was 0.47 per cent. That is quite high, given the fact that only tree variables (lifestyle risk, normalessness and micro-place disorder) are taken into account. The fully integrated model that includes subjective powerlessness and the integrative control model are nested, thus they can be compared using a difference in deviance test (Bollen 1996). The deviance difference between the micro-place disordercontrol model and the micro-place disorderpowerlessness-control model was statistically significant $(p<0.01)$.

\section{CONCLUSION AND DISCUSSION}

This study began with questioning the relationship between micro-place disorder, subjective powerlessness and VYG. We argued that it was highly plausible that multiple links were to be expected, at least from the standpoint of an integrated micro-place disorder-powerlessness-control theory. To test possible relationships between micro-place disorder, subjective powerlessness and VYG a large-scale youth survey was conducted in Antwerp. Since this was a crosssectional study, we do not know these adolescents' past childhood development, and we do not how they have developed since they participated in the study. Therefore we cannot explain how these individual differences have emerged and cannot say how their current youth group involvement will affect their future lives. Unfortunately the cross-sectional study design poses enormous restriction. One such restriction is the selection effect. It is important that future studies take the selection effect seriously and make efforts to study. A technique that is recently used to control for selection effects is propensity score matching (for an example in gang research, see: Pyrooz 2014). Further, it is paramount for future research to study entry and disengagement seriously as separate concepts, that may have a distinct etiology (Melde and Esbensen 2011; Sweeten, Pyrooz and Piquero 2013). The aim of this study was more modest: to assess the effect of subjective powerlessness in an integrated framework that is capable of explaining who reports violent youth group involvement in early adolescence. This framework should be tested using panel data to increase our understanding of the effects of subjective powerlessness.

Multiple pathways were identified from micro-place disorder to VYG. In line with the integrative theory, micro-place disorder matters regarding parental control and subjective powerlessness. Parental monitoring had multiple effects on VYG, both direct and indirect effects. The effect of subjective powerlessness should however not be overestimated. It is entirely mediated by normlessness and low self-control. Normlessness seemed to be a crucial mediator for the effect of parental control. Contrary to previous studies, this study did not find any direct effects of low self-control on VYG. Lifestyle risk fully mediated the effect of low self-control and was one of the strongest predictors of VYG. Adopting a street-oriented lifestyle affects the likelihood of becoming involved in a violent youth group. That may be so because gang members actively recruit or because the risky lifestyle increases the likelihood of getting in contact. Theoretically a risky lifestyle can have a selection effect, a socialization effect and a facilitating effect. Unfortunately on panel study of gang membership has ever taken place in Belgium. The risky lifestyle is especially related to low self-control and normlessness.

We do not doubt the relevance of test alternative models of VYG that incorporate mechanisms that are sometimes discussed, but rarely tested, such as subjective powerlessness. But as we have tested a theory in youths in early adolescents using a crosssectional model, this model is not able to fully capture 
what is going on over time. While the integrative theory is built on causal arrows that go in one way, we believe for a number of reasons that this is an oversimplification. First of all, a number of longitudinal studies, such as the ones referred to by Thornberry and colleagues have demonstrated that there are reciprocal effects over time. It is unclear at the moment to what extent violent youth group involvement in itself is related to subjective powerlessness over time. That is an interesting question that remains unanswered. It is plausible that a relation exists between subjective powerlessness and the individual length of an individual's career as a gang member. If such a relationship would exist, the strength of that relationship might depend on the nature of the group and the functions and social roles that the individual fulfills. Violent youth group involvement is likely to reinforce normlessness over time, just like it intensifies offending (Melde and Esbensen 2011). As Ross and Mirowsky (2009) correctly observed, subjective powerlessness is higher in micro-places that are characterized by high levels of disorder. The negative world view that one is not in control (i.e. fatalism) is an additional mechanism in the development of normlessness and low self-control, which in turn has strong consequences for lifestyle risk and ultimately for VYG. Most micro-place theories stress that micro-place effects are indirect through their impact on informal controls such as parental control. We have tested an additional link. Future research might also want to study the effect of repeat victimization on subjective powerlessness. Despite these restrictions, we think our finding is important for theory and practice. Also in Belgium a small number of young adolescents selfreport violent youth group involvement. In our sample the percentage was 8.1. This underscores the urgent need for effective gang-resistance education programs and other primary and secondary prevention and intervention initiatives directed at youths in early adolescence, especially those that are prone to a risky lifestyle and have low self-control, have high scores on normlessness and subjective powerlessness. The new implication of our finding for theories of VYG is that we have demonstrated that the relationship between observed micro-place disorder and VYG is not just a matter of social controls, self-control and lifestyle risk but also a matter of subjective powerlessness. Subjective powerlessness fits in as a concept in Wood and Alleyne's (2010) unified framework of gang membership but it may also fit in Thornberry's interactional theory. The study of subjective powerlessness is important for practitioners and individuals that are high in subjective powerlessness are harder to motivate than individuals that are low in subjective powerlessness. Young adolescents that are high in subjective powerlessness need special attention in training programmes.

Appendix: $\quad$ Constructs with Factor Loadings and Alpha Values

\begin{tabular}{|c|c|c|c|}
\hline Likert Scale construct & & $\begin{array}{l}\text { Factor } \\
\text { loading }\end{array}$ & $\begin{array}{l}\text { ALPHA } \\
\text { Value }\end{array}$ \\
\hline Parental control & $\begin{array}{l}\text { My parents/caretakers know with whom I hang around when I am not at home. } \\
\text { My parents/caretakers know where I am when I am not at home. } \\
\text { My parents/caretakersknow how I behave when I am not home } \\
\text { When I have to go to school the next day, I need to be in bed on time } \\
\text { If I am with friends, I need to be home at an agreed hour }\end{array}$ & $\begin{array}{l}.645 \\
.743 \\
.625 \\
.439 \\
.454\end{array}$ & .709 \\
\hline Subjective powerlessness & $\begin{array}{l}\text { I often have the feeling of getting into trouble beyond my control } \\
\text { I believe that planning does not guarantee success } \\
\text { Working hard is useless, its seldom pays off for me }\end{array}$ & $\begin{array}{l}.566 \\
.615 \\
.520\end{array}$ & .586 \\
\hline Legal cynicism & $\begin{array}{l}\text { Rules are made to be broken } \\
\text { It is ok to break rules, as long as you don't get caught } \\
\text { It is ok to fight if you are challenged } \\
\text { If I don't succeed using honest methods, then I use unfair methods }\end{array}$ & $\begin{array}{l}.668 \\
.772 \\
.639 \\
.680\end{array}$ & .783 \\
\hline Lifestyle Risk & Life style routines risk & & \\
\hline Peer delinquency & $\begin{array}{l}\text { How many of your friends have ever stolen something or taken away money? } \\
\text { How many of your friends have ever hit someone with the consequence that this } \\
\text { person needed medical care? } \\
\text { How many of your friends have ever destroyed or damaged something? }\end{array}$ & $\begin{array}{l}.697 \\
.684 \\
.682\end{array}$ & .719 \\
\hline
\end{tabular}




\begin{tabular}{|c|c|c|c|}
\hline $\begin{array}{l}\text { Lifestyle/Routines risk } \\
\text { indicator questions }\end{array}$ & $\begin{array}{l}\text { Sum of distribution risk scores (coded } 1 \text { if risk end, }-1 \text { if protective end of } \\
\text { distribution, and } 0 \text { if in between) } \\
\text { How often are you out on streets (never/sometimes/often)+ } \\
\text { Quartiles of rule breaking of friends + }\end{array}$ & -- & -- \\
\hline Low self-control & Used items (combined scale: alpha 0.78 & $\begin{array}{l}\text { Factor } \\
\text { loading }\end{array}$ & $\begin{array}{l}\text { ALPHA } \\
\text { Value }\end{array}$ \\
\hline Temper & $\begin{array}{l}\text { When I am angry, others had better stay out of my way } \\
\text { When I am angry with someone, l'd rather hit then talk, } \\
\text { I get angry easily }\end{array}$ & $\begin{array}{l}.637 \\
.617 \\
.659\end{array}$ & .671 \\
\hline Impulsiveness & $\begin{array}{l}\text { I often do things without thinking } \\
\text { If I can have fun immediately, I'll do it, even if I get in trouble later } \\
\text { I say what I think, even if it is not smart } \\
\text { I often do immediately what I feel like doing }\end{array}$ & $\begin{array}{l}.583 \\
.666 \\
.586 \\
.665\end{array}$ & .717 \\
\hline Micro-place disorder & $\begin{array}{l}\text { Neighborhood inhabitants quarreling on the street } \\
\text { Elder people being angry with youth } \\
\text { Someone trying to hide something in a shopping bag in a local store to steal it } \\
\text { Garbage and/or dirt being on the sidewalk } \\
\text { A group of local youth harassing someone to get money or something else of } \\
\text { value } \\
\text { House fronts, doors etc. being covered with graffiti } \\
\text { A couple of men drinking alcohol (beer, etc.) in the street (e.g.: at a bus- stop or } \\
\text { local supermarket) } \\
\text { Someone selling drugs (hash, marijuana, etc.) on the streets } \\
\text { Someone being threatened with a weapon on the street (fire arm, knife, etc.) } \\
\text { A youngster starting a fight because he or she has been challenged by other } \\
\text { youth }\end{array}$ & $\begin{array}{l}.549 \\
.515 \\
.612 \\
.515 \\
.698 \\
.467 \\
.605 \\
.671 \\
.662 \\
.669\end{array}$ & .841 \\
\hline
\end{tabular}

\section{REFERENCES}

Alleyne, Emma, and Jane L. Wood. 2010. "Gang involvement: Psychological and behavioral characteristics of gang members, peripheral youth, and nongang youth." Aggressive behavior 36.6: 423-436. http://dx.doi.org/10.1002/ab.20360

Bandura, Albert. 1986. Social learning theory. Englewood Cliffs, NJ: Prentice-Hall.

Bernasco, Wim, Stijn Ruiter, Gerben J.N. Bruinsma, Lieven J.R. Pauwels and Frank M. Weerman2013. "Situational Causes of Offending: A Fixed-Effects Analysis of Space-Time Budget Data". Criminology, 51(4): 895-926. http://dx.doi.org/10.1111/1745-9125.12023

Bernburg, Jon-Gunnar and Thorolfur Thorlindsson. 2005. "Violent values, conduct norms, and youth aggression: A multilevel study in Iceland". The Sociological Quarterly, 46 (3): 457478.

http://dx.doi.org/10.1111/j.1533-8525.2005.00022.x

Bollen, Kenneth. A. 1998. Structural equations with latent variables. Wiley series in probability and mathematical statistics. New York, NY: Wiley.

Braga, Anthony A., Andrew V. Papachristos, and David M. Hureau. 2010. "The concentration and stability of gun violence at micro places in Boston, 1980-2008." Journal of Quantitative Criminology 26.1: 33-53. http://dx.doi.org/10.1007/s10940-009-9082-x

Brutsaert, Herman. 2001. Co-educatie: Studiekansen en kwaliteit van het schoolleven. Leuven: Garant.

Bursik Jr, Robert J. and Harold G. Grasmick. 1993. Neighborhoods and Crime. Lexington Books.
Bunge, Mario. 2012 [1959]. Causality and modern science. Courier Dover Publications.

Byrne, B. M. 2011. Structural equation modeling with Mplus: Basic concepts, applications, and programming. New York, NY: Routledge Academic.

Chapple, Constance L. and Trina L. Hope. 2003. "An analysis of the self-control and criminal versatility of gang and dating violence offenders." Violence and Victims 18 (6): 671-690. http://dx.doi.org/10.1891/vivi.2003.18.6.671

Cloward, Richard A. and Lloyd E. Ohlin. 1960. Delinquency and Opportunity. New York, NY: Free Press.

Cohen, Albert. 1955. Delinquent boys: The culture of the gang. Glencoe, IL: The Free Press.

Curry, G. David, Scott H. Decker and David Pyrooz. 2003. Confronting gangs: Crime and community. Roxbury Publishing Company.

Decker, Scott H. and Frank M. Weerman, eds.2005. European street gangs and troublesome youth groups Nolume 3). Rowman Altamira.

Decker, Scott H., Chris Melde and David C. Pyrooz. 2013. "What do we know about gangs and gang members and where do we go from here?." Justice Quarterly 30.3: 369-402. http://dx.doi.org/10.1080/07418825.2012.732101

Diehl, M. and Hay, E. L. (2010). "Risk and resilience factors in coping with daily stress in adulthood: the role of age, self-concept incoherence, and personal control." Developmental psychology, 46(5): 1132-1146. http://dx.doi.org/10.1037/a0019937

Duke, M. P. and Fenhagen, E. (1975). Self-parental alienation and locus of control in delinquent girls. Journal of Genetic Psychology, 127, 103-107. http://dx.doi.org/10.1080/00221325.1975.10532360 
Durkheim, Emile. 1893. De la division du travail social. Paris: Les Presses universitaires de France. (original book online available).

Elster, Jon. 1989. Nuts and bolts for the social sciences. Cambridge: Cambridge University Press. http://dx.doi.org/10.1017/CBO9780511812255

Esbensen, Finn A., Dana Peterson, Terence J. Taylor, Adrienne Freng. 2010. Youth violence: Sex and race differences in offending, victimization, and gang membership. Temple, PA: Temple University Press.

Felson, Marcus and Rachel L. Boba, eds.2010. Crime and everyday life. $\left(4^{\text {th }}\right.$ edition). Thousand Oaks, CA: Sage. http://dx.doi.org/10.4135/9781483349299

Forde, David R. and Leslie W. Kennedy. 1997. "Risky lifestyles, routine activities, and the general theory of crime." Justice Quarterly 14 (2): 265-294. http://dx.doi.org/10.1080/07418829700093331

Gatti, Uberto, Richard R. Tremblay, Frank Vitaro and Pierre McDuff,. 2005. "Youth gangs, delinquency and drug use: A test of the selection, facilitation, and enhancement hypotheses." Journal of Child Psychology and Psychiatry, 46(11): 1178-1190. http://dx.doi.org/10.1111/j.1469-7610.2005.00423.x

Geis, Karlyn J. and Catherine E. Ross. 1998. "A new look at urban alienation: the effect of neighborhood disorder on perceived powerlessness." Social Psychology Quarterly, 61(3), 232246 http://dx.doi.org/10.2307/2787110

Gottfredson, Michael and Travis Hirschi. 1990. A General Theory of Crime. Stanford, CA: Stanford California Press.

Grasmick, Harold G., Charles R. Tittle, Robert C. Bursik and Bruce J. Arneklev. 1993. "Testing the core empirical implications of Gottfredson and Hirschi's general theory of crim". Journal of Research in Crime and Delinquency, 30(1): 5-29. http://dx.doi.org/10.1177/0022427893030001002

Smith, Hayden P., and Robert M. Bohm. 2008. "Beyond anomie: Alienation and crime." Critical Criminology 16(1): 1-15. http://dx.doi.org/10.1007/s10612-007-9047-z

Hedström, Peter. 2005. Dissecting the social: On the principles of analytical sociology. Cambridge: Cambridge University Press.

http://dx.doi.org/10.1017/CBO9780511488801

Hope, Trina L. and Kelly R. Damphousse. 2002. "Applying selfcontrol theory to gang membership in a non-urban setting." Journal of Gang Research 9 (2): 41-61.

Guterman, Neil B., Shawna J. Lee, Catherine A. Taylor and Paul J. Rathouz. 2009. "Parental perceptions of neighborhood processes, stress, personal control, and risk for physical child abuse and neglect". Child abuse \& neglect, 33(12): 897-906. http://dx.doi.org/10.1016/j.chiabu.2009.09.008

Haynie, Dana L. and D. Wayne Osgood. 2005. "Reconsidering Peers and Delinquency: How Do Peers Matter?" Social Forces, 84(2): 1109-1130.

http://dx.doi.org/10.1353/sof.2006.0018

Hirschi, Travis.1969. Causes of delinquency. New Brunswick, NJ: Transaction Publishers.

Jean, Peter K.B. St. 2008.Pockets of crime: Broken windows, collective efficacy, and the criminal point of view. Chicago: University of Chicago Press.

Jones, Shayne and Donald R. Lynam. 2009. "In the Eye of the Impulsive Beholder the Interaction Between Impulsivity and Perceived Informal Social Control on Offending." Criminal Justice and Behavior, 36(3): 307-321. http://dx.doi.org/10.1177/0093854808328653

Jurkovic, Gregory J. 1980. "The juvenile delinquent as a moral philosopher: A structural-developmental perspective." Psychological Bulletin, 88: 709-727. http://dx.doi.org/10.1037/0033-2909.88.3.709
Jöreskog, Karl G. and Dag Sörbom.1993. LISREL 8 User's reference guide. Chicago, IL: Scientific Software International.

Katz, Charles.M. and Andrew M. Fox. 2010. "Risk and protective factors associated with gang-involved youth in Trinidad and Tobago." Revista Panamericana de Salud Pública, 27(3): 187-202.

http://dx.doi.org/10.1590/S1020-49892010000300006

Kissner, Jason and David C. Pyrooz. 2009."Self-control, differential association, and gang membership: A theoretical and empirical extension of the literature." Journal of Criminal Justice 37.5: 478-487. http://dx.doi.org/10.1016/j.jcrimjus.2009.07.008

Kornhauser, Ruth R.1978. Social sources of delinquency. Chicago, IL: University of Chicago Press.

Lau, Sing, Cyril Figuerres and J. Kent Davis. "Re-examination of the relationship between locus of control and field independence/dependence." Perceptual and Motor Skills 53.2 (1981): 555-561. http://dx.doi.org/10.2466/pms.1981.53.2.555

Lau, Sing and Kwok Leung. 1992. "Self-concept, delinquency, relations with parents and school and Chinese adolescents' perception of personal control." Personality and Individual Differences 13 (5): 615-622. http://dx.doi.org/10.1016/0191-8869(92)90203-2

Lefcourt, Herbert M. ed. 1982. Locus of control: Current trends in theory and research. London: Psychology Press.

Leung, Kwokand Sing Lau. 1989. "Effects of self-concept and perceived disapproval on delinquent behavior in school children." Journal of Youth and Adolescence, 18: 345-359. http://dx.doi.org/10.1007/BF02139254

Maxfield, Michael G.1987. "Lifestyle and routine activity theories of crime: Empirical studies of victimization, delinquency, and offender decision-making." Journal of Quantitative Criminology 3 (4): 275-282.

http://dx.doi.org/10.1007/BF01066831

Melde, Chris and Finn-Aage Esbensen. 2011. "Gang membership as a turning point in the life course." Criminology, 49(2), 513552. http://dx.doi.org/10.1111/j.1745-9125.2011.00227.x

Messner, Steven. F., Krohn, Marvin D. and Allan E. Liska, eds.. 1989. Theoretical integration in the study of deviance and crime: Problems and prospects. New York: SUNY Press.

Miller, Walter. 1958. "Lower Class Culture as a Generating Milieu of Gang Delinquency." Journal of Social Issues, 14, 5-20. http://dx.doi.org/10.1111/j.1540-4560.1958.tb01413.x

Mirowsky, John and Catherine E. Ross. 2003. Social causes of psychological distress (2nd edition). Hawthorne, NY: Aldine De Gruyter.

Muthén, Linda K. and Bengt Muthén. 2011. Mplus user's guide (6th ed.), Los Angeles, CA.

Oberwittler, Dietrich. 2004. "A Multilevel Analysis of Neighbourhood Contextual Effects on Serious Juvenile Offending The Role of Subcultural Values and Social Disorganization." European Journal of Criminology, 1(2): 201-235. http://dx.doi.org/10.1177/1477370804041248

Oberwittler, Dietrich, and Per-Olof H. Wikström. 2009. "Why small is better: Advancing the study of the role of behavioral contexts in crime causation." 35-59. In: David Weisburd, WimBernasco and GerbenBruinsma, eds. Putting crime in its place. Springer New York, 2008.

Opp, Karl-Dieter. 2009. Theories of political protest and social movements: A multidisciplinary introduction, critique, and synthesis. Routledge.

Osgood, D. Wayne, andAmy L. Anderson. 2004. "Unstructured socializing and rates of delinquency." Criminology, 42(3): 519-550. http://dx.doi.org/10.1111/j.1745-9125.2004.tb00528.x 
Osgood, D. Wayne., Janet K. Wilson, Patrick M. O’Malley, Jerald G. Bachman and Lloyd D. Johnston. 1996. "Routine activities and individual deviant behavior." American Sociological Review, 61: 635-655.

http://dx.doi.org/10.2307/2096397

Parrot, Andrew C. and Kenneth T. Strongman. 1984. "Locus of control and delinquency." Adolescence, 19, 459-471.

Pauwels, Lieven. 2010. Violent youth group involvement in context: the case of Antwerp. In: Lieven Pauwels, Wim Hardyns and Maarten Van de Velde, eds. Social disorganisation, offending, fear and victimisation. Findings from Belgian studies on the urban context of crime. Den Haag: Boom Juridische Uitgevers.

Pauwels, Lieven J.R., Wim Hardynsand Maarten Van de Velde. 2010. Social disorganisation, offending, fear and victimisation: findings from Belgian studies on the urban context of crime. Boom Legal Publishers: The Hague.

Pauwels, Lieven. 2012. Social disorganisation and adolescent offending in Antwerp. A multilevel study of the effect of neighbourhood disadvantage on individual involvement in offending (133-166). In: Paul Ponsaers, Ed. Social Analysis of Financial, Economic and Ecological Crime Crime, (In)security and (Dis)trust, Public and Private Policing Security. Antwerpen: Maklu.

Pauwels, Lieven.2013. Adolescent offending and disadvantage in urban neighbourhoods and schools. A cross-classified multilevel analysis In: Dietrich Oberwittler Suzanne RaboldandDirk Baier, eds. Städtische Armutsquartiere Kriminelle Lebenswelten? Studienzusozialräumlichen Kontexteffekten auf Jugendkriminalität und Kriminalitätswahrnehmungen. Wiesbaden: VS Verlag für Sozialwissenschaften.

Pauwels, Lieven .J.R. and Robert Svensson. 2013. "Violent Youth Group Involvement, Self-reported Offending and Victimization: An Empirical Assessment of an Integrated Informal Control/Lifestyle Model."European Journal of Criminal Policy \& Research. Online First. http://dx.doi.org/10.1007/s10610-013-9205-7

Pearlin, Leonard I., Morton A. Lieberman, Elizabeth G. Menaghan, Joseph T. Mullen. (1981). "The Stress Process." Journal of Health and Social Behavior 22:337-56.

http://dx.doi.org/10.2307/2136676

Portes, A. 1971. "Political primitivism, differential socialization, and lower-class leftist radicalism." American sociological review, 820-835.

http://dx.doi.org/10.2307/2093669

Pratt, Travis. C. and Francis T. Cullen. 2000. "The Empirical Status of Gottfredson and Hirschi's General Theory of Crime: A Meta-Analysis." Criminology, 38(3): 931-964.

Ransford, H. E. 1968. Isolation, powerlessness, and violence: a study of attitudes and participation in the Watts riot. American Journal of Sociology, 73, 58 I-591.

Pyrooz, David C. 2014. "'From Your First Cigarette to Your Last Dyin' Day": The Patterning of Gang Membership in the LifeCourse." Journal of Quantitative Criminology 30 (2): 349-372. http://dx.doi.org/10.1007/s10940-013-9206-1

Pyrooz, David C. "From colors and guns to caps and gowns? The effects of gang membership on educational attainment." Journal of research in crime and delinquency 51 (1): 56-87.

Pyrooz, David C., and Alejandro A. Ferrer.2014. "Gangs: Theories of Involvement and Behavior." In: J. Mitchell Miller, The Encyclopedia of Theoretical Criminology, Wiley, 1-4. http://dx.doi.org/10.1002/9781118517390.wbetc159

Reckless, Walter. C.1961. "New Theory of Delinquency and Crime." A. Fed. Probation, 25: 42.

Riley, David. 1987. "Time and crime: The link between teenager lifestyle and delinquency." Journal of Quantitative Criminology, 3(4), 339-354. http://dx.doi.org/10.1007/BF01066835
Ross, Catherine. E. and John Mirowsky. 1987. Normlessness, Powerlessness, and Trouble with the Law. Criminology, 25: 257-278. http://dx.doi.org/10.1111/j.1745-9125.1987.tb00797.x

Ross, Catherine. E.andJohn Mirowsky. 2001. "Neighborhood disadvantage, disorder, and health." Journal of Health and Social Behavior, 42:258-76. http://dx.doi.org/10.2307/3090214

Ross, Catherine. E., John Mirowsky and Shana Pribesh. 2001. "Powerlessness and the amplification of threat: Neighborhood disadvantage, disorder, and mistrust." American Sociological Review, 66:568-91. http://dx.doi.org/10.2307/3088923

Ross, Catherine E., John Mirowskyand Shana Pribesh.2002. "Disadvantage, disorder and urban mistrust." City and Community, 1:59-82.

http://dx.doi.org/10.1111/1540-6040.00008

Ross, Catherine E. and Mirowsky, J. 2009. "Neighborhood Disorder, Subjective Alienation, and Distress." Journal of Health and Social Behavior 50:49-64. http://dx.doi.org/10.1177/002214650905000104

Rotter, Julian B. 1966. "Generalized expectancies of internal versus external control of reinforcements." Psychological Monographs, 80(1, Whole No. 609).

Sampson, Robert. J., Stephen W. Raudenbush, and Felton Earls. 1997. "Neighborhoods and violent crime: A multilevel study of collective efficacy." Science, 277: 918-924. http://dx.doi.org/10.1126/science.277.5328.918

Sampson, Robert J. and Dawn Jeglum Bartusch. 1998. "Legal cynicism and (subcultural?) tolerance of deviance: The neighborhood context of racial differences." Law and Society Review, 32: 777-804. http://dx.doi.org/10.2307/827739

Seeman, Melvin. 1959. "On The Meaning of Alienation." American Sociological Review, 24(6): 783-791. http://dx.doi.org/10.2307/2088565

Seeman, M. 1972. Alienation and engagement. Pp. 467-527. In: A. Campbell and P. E. Converse eds., The Human Meaning of Social Change. New York: Russell Sage.

Seeman, Melvin. 1983. "Alienation Motifs in Contemporary Theorizing: The Hidden Continuity of Classic Themes." Social Psychology Quarterly 46:171-84. http://dx.doi.org/10.2307/3033789

Sharp, Clare., Judith Aldridge and Juanjo Medina. 2006. Delinquent youth groups and offending behaviour: Findings from the 2004 Offending, Crime and Justice Survey. Home Office Online Report 14/06, London, UK: Home Office.

Short, James. F. and Fred L. Strodtbeck. 1965. Group process and gang delinquency. Chicago: University of Chicago Press.

Skogan, Wesley. G. 1990. Disorder and decline: Crime and The Spiral of Decay in American Neighbourhoods. University of California Press

Smith, William. R., Sharon G. Frazee and Elisabeth L. Davison. 2000. "Furthering the integration of routine activity and social disorganization theories: Small units of analysis and the study of street robbery as a diffusion process." Criminology, 38(2), 489-524. http://dx.doi.org/10.1111/j.1745-9125.2000.tb00897.x

Srole, Leo. 1956. "Social Integration and Certain Corollaries: An Exploratory Study." American Sociological Review, 21: 709716. http://dx.doi.org/10.2307/2088422

Svensson, Robert and Lieven J.R. Pauwels. 2010. "Is a risky lifestyle always "risky"? The interaction between individual propensity and lifestyle risk in adolescent offending: $A$ test in two urban samples. Crime \& Delinquency, 56(4): 608-626. http://dx.doi.org/10.1177/0011128708324290 
Sweeten, Gary, David C. Pyrooz, and Alex R. Piquero. 2013. "Disengaging from gangs and desistance from crime." Justice Quarterly 30 (3): 469-500. http://dx.doi.org/10.1080/07418825.2012.723033

Thorlindsson, Thorolfur and Jon-GunnarBernburg. 2004. "Durkheim's theory of social order and deviance: a multi-level test." European Sociological Review, 20(4): 271-285. http://dx.doi.org/10.1093/esr/jch025

Thornberry, Terence P.1987. "Toward an interactional theory of delinquency." Criminology 25.4: 863-892. http://dx.doi.org/10.1111/j.1745-9125.1987.tb00823.x

Thornberry, Terance. P., Marvin D. Krohn, Lizotte, Alan. J. and Deborah J. Chard-Wierschem. 1993. "The role of juvenile gangs in facilitating delinquent behavior." Journal of Research in Crime and Delinquency, 30(1), 55-87. http://dx.doi.org/10.1177/0022427893030001005

Thornberry, Terance.P., Marvin Krohn, Alan J. Lizotte and Carolyn A. Smith. 2003. Gangs and delinquency in developmental perspective. Cambridge, UK: Cambridge University Press.

Thornberry, Terrence P., J. David Hawkins, and Marvin D. Krohn. 1998. Gang membership, delinquent peers, and delinquent behavior. Washington, DC: US Department of Justice, Office of Justice Programs, Office of Juvenile Justice and Delinquency Prevention.

Thrasher, Frederic. M. (1927). The Gang. Chicago, IL: University of Chicago Press.
Vowell, Paul R. 2007. "Partial Test of an Integrative Control Model: Neighborhood Context, Social Control, Self-Control, and Youth Violent Behavior, A." W. Criminology Rev. 8: 1-15.

Weisburd, David L., Elizabeth R. Groff, and Sue-Ming Yang. 2012. The criminology of place: Street segments and our understanding of the crime problem. Oxford University Press. http://dx.doi.org/10.1093/acprof:oso/9780195369083.001.000 1

Wikström, Per-Olof. H. and David. A. Butterworth. 2006. Adolescent Crime. Willan Publishing.

Wikström, Per-Olof H., and Robert J. Sampson. 2003. "Social mechanisms of community influences on crime and pathways in criminality." 118-148. In: Lahey, Benjamin B., Terrie E. Moffitt and Avshalom Caspi, eds. Causes of conduct disorder and juvenile delinquency. Guilford Press.

Wikström, Per-Olof H. 2012. "Individuals' Situational Criminal Actions: Current Knowledge and Tomorrow's Prospects". 5561. In: Loeber, Rolf, and Brandon C. Welsh, eds. The future of criminology. Oxford University Press, 2012.

Wikström, Per-Olof H, Dietrich Oberwittler, Kyle Treiber and Beth Hardie, B. 2012. Breaking rules: The social and situational dynamics of young people's urban crime. Oxford: Oxford University Press.

Wood, Janeand Emma Alleyne. 2010. "Street gang theory and research: Where are we now and where do we go from here?" Aggression and Violent Behavior, 15, 100-111. http://dx.doi.org/10.1016/j.avb.2009.08.005

DOI: http://dx.doi.org/10.6000/1929-4409.2014.03.18

(C) 2014 Pauwels and Svensson; Licensee Lifescience Global.

This is an open access article licensed under the terms of the Creative Commons Attribution Non-Commercial License (http://creativecommons.org/licenses/by-nc/3.0/) which permits unrestricted, non-commercial use, distribution and reproduction in any medium, provided the work is properly cited. 